\title{
THE LEICESTERSHIRE MINERS AND THE MINING DISPUTE OF 1926
}

Leicestershire is one of the East Midland's smaller coalfields, though it was growing faster than any other coalfield in the two decades before the First World War, ${ }^{1}$ and its output, and number of persons employed, unlike those of many far larger coalfields, were greater in 1925 than they had been in $1913 .^{2}$ Annual average earnings per shift were also among the highest in the country and the level of unemployment among the miners was relatively low by coal-mining standards. ${ }^{3}$ The Leicestershire Miners' Association had 7,428 members at the end of 1925, which represented about three-quarters of the coal-miners employed in the coalfield, ${ }^{4}$ and relations with the coal-owners were by tradition peaceful with the owners agreeing to assist the LMA's "closed shop" policy and allowing union business to be conducted on colliery premises. ${ }^{5}$ The Leicestershire coalfield was one of that select band of inland coalfields that enjoyed relative prosperity in the early 1920 's, and this state of affairs was reflected in the fact that the owners did not lock their men out to enforce either reduced wages or increased hours in May $1926,{ }^{6}$ but rather the miners struck in support of the policies of the Miners' Federation of Great Britain, to which they had been affiliated since its inception in $1889 .^{7}$

Despite the fact that the LMA had achieved a high level of unionisation in the coalfield, its financial position at the end of $1925(£ 24,029$

1 J. W. F. Rowe, Wages in the Coal Industry (London, 1923), pp. 26-28; C. P. Griffin, "Economic and Social Development of the Leicestershire and South Derbyshire Coalfield 1550-1914" (unpublished Ph.D. thesis, Nottingham, 1970), p. 919.

${ }^{2}$ His Majesty's Inspector of Mines, Annual Report, 1930.

3 Leicestershire Miners' Association Minute Book (hereafter LMA), 4 May 1928; His Majesty's Inspector of Mines, Annual Report, 1935.

4 Annual Report of the Chief Registrar of Friendly Societies, 1925.

'Griffin, op. cit., p. 667; Miners' Federation of Great Britain Minute Book (hereafter MFGB), 2 June 1927.

( LMA, 12 July 1926; Coalville Times, 30 April.

7 Griffin, op. cit., p. 670. 
in balance) was weak, ${ }^{\mathbf{1}}$ and had not improved by the time the dispute commenced. Full dispute pay was only paid once, and after further payments of one half pay and two quarter pays union funds were declared to be exhausted. ${ }^{2}$ This was on 18 June, six weeks after the stoppage had commenced. Thereafter income received from the MFGB enabled one-fifth payment to be authorised on 21 June and 9 August, and a one-tenth payment was made on 10 September, ${ }^{3}$ by which time the stoppage was, as we shall see, effectively over in Leicestershire. Many families were forced to apply to the Poor Law guardians for assistance, which mainly took the form of loans. School soup kitchens were active throughout the stoppage, and the condition of footwear in the coalfield became so poor by August that the Women's Committee for the relief of distressed miners and their families (an ad hoc committee of the Women's Institute) organised a boot-andshoe-repair service. ${ }^{4}$ The miners ran up yards of credit at local shops, and when this ran out the LMA made an unsuccessful attempt to borrow $£ 15,000$ in the form of credit vouchers for its members from Coalville Co-operative Society. ${ }^{5}$ There is no doubt that the words of William Carter, a loyal member of the Nottinghamshire Miners' Association Executive speaking of his own district, that "I know, as good Trades Unionists as I am, who have had to return to work, and had we been able to give money, hundreds and thousands would have refrained from going back to work"6 equally apply to Leicestershire. Indeed an LMA official reported on one occasion: "Men have been to me, strong men who could have killed you had they wished, have cried to me, saying they have been compelled to go to work, the men are starving"'?

The LMA commenced the strike with an additional weakness, a deep-rooted animosity, which the strike exacerbated, between its two full-time officials, John W. Smith, agent, and Thomas Growdridge, secretary, the latter being backed by a majority of the members of the Executive Council. Smith had been in dispute with the Executive since July 1925 over the amount of his salary, and was also in the habit of holding public meetings which he was not strictly speaking entitled to call. ${ }^{8}$ Smith was also a member of the MFGB Executive

\footnotetext{
1 Annual Report of the Chief Registrar of Friendly Societies, 1925.

2 LMA, 14 and 28 May, 11 and 18 June 1926.

${ }^{3}$ Ibid., 21 June, 9 August and 10 September.

4 Ibid., 9 and 16 August, 22 November; Colliery Guardian, 17 September.

5 Ibid., 6 September.

${ }^{6}$ MFGB, 4 November 1926.

7 Ibid., 4 and 19 November.

8 LMA, 24 September 1925, 10 and 19 March 1926; Colliery Guardian, 24 April 1925.
} 
and a die-hard supporter of the no-compromise-settlement line within it, a position which he made perfectly clear in this attack on the negotiations being undertaken by the Executive to achieve a compromise settlement in May 1926: "We are sapping too much of the energy of our men in casting doubt on the solidarity of the Federation and the districts [...]. We must leave it to the majority to decide and we ought not to attempt to bring discord amongst our allies by talking about a compromise". ${ }^{1}$ Smith also made, not surprisingly, bitter attacks on the Leicestershire owners throughout the stoppage, as when he greeted an offer made by them to tempt the miners back to work thus: "We have been through strikes before and for what the offer is worth we might as well accept proposals from Joe Boot of Whitwick [a local simpleton]", ${ }^{2}$ or when he argued:

"Daylight robbery is going on in the coalmining industry and the owners are afraid of an honest deal [...]. If capitalism cannot find the means of existence for the whole of the race, it must make way for some saner system which will do so. [...] if the country cannot afford to pay the miners a living wage, let the capitalists train some of their own sons to go and get coal."3

His opponents within the LMA Executive did not share his views, but rather recommended acceptance of all the initiatives made to end the struggle between May and November 1926, and disassociated themselves from Smith's "revolutionary talk". 4 Smith compounded his offence by spending what the LMA Executive regarded as an excessive amount of time on MFGB business, and when Smith was reprimanded for his failure to devote sufficient attention to organising the dispute in Leicestershire he reacted by calling an unauthorised meeting at Coalville, during which he justified his actions and criticised his colleagues for their lack of enthusiasm for the strike. ${ }^{5}$ Smith's attitude was very much a minority one within the LMA, and the weakness of the rank-and-file support revealed itself initially in a report made on 18 June that men other than the permitted number of "safety men" had been working at Ibstock colliery since the LMA had run out of funds. ${ }^{6}$ Smith put a brave face on the situation:

"There is a critical situation in the mining industry and there must be a great struggle with the owners. I am not preaching

1 MFGB, 1 May 1926.

${ }^{2}$ Coalville Times, 30 July 1926.

3 Ibid., 6 August.

4 LMA, 4 August and 1 October 1926; Coalville Times, 4 March 1927.

${ }^{5}$ LMA, 30 June 1926; Coalville Times, 2 July.

- LMA, 18 June. 
revolution but $I$ cannot conceive the miners remaining passive and peaceful for another three months [...]. Though our funds are depleted the owners should not count on that [...]; we will fight as we have never fought before."1

The owners were not impressed with Smith's defiance, and unsuccessfully tried three times in July to persuade the LMA Executive to meet them "to consider with them, without prejudice, the present situation of the coal industry in Leicestershire". ${ }^{2}$ During August men were drifting back to work at two collieries and outcrop working of coal had reached large proportions. ${ }^{3}$ Smith imagined that he could discern the cause of Leicestershire's difficulties:

"It is not, as one speaker has suggested here already, a weakness demonstrated, shall I say, on the stomachs of the women and children; [...] it is the disloyalty of the members of our own movement which is undermining the stability of our movement. [...] we have to remember [...] that things have been demonstrated in my neighbouring county [Nottinghamshire] which is not the weakness of the women and children, afraid of not getting meals, but it is men who have got full stomachs that $I$ am afraid of."4

Smith was referring to the fact that the Nottinghamshire Miners' Association Council had passed a resolution recommending negotiations with the Nottinghamshire owners and had applied to the MFGB Executive for authority to conduct district negotiations. ${ }^{5}$ He claimed that this was an act of defeatism, which was spreading dispondency in Leicestershire because the very idea of district negotiations at this stage of the dispute was disheartening and, in any case, such action was demoralising Nottinghamshire miners to the extent that they were drifting into Leicestershire and undermining the confidence of the workforce there, who feared that their jobs would be permanently taken by Nottinghamshire men," and added, for good effect: "I want you to realise my difficulty, when we have leaders in the same districts who have said amongst other things that Herbert Smith had crawled on his belly, and the sooner there were district agreements the better [...]. The question this Conference must answer is this:

1 Coalville Times, 28 May.

2 LMA, 12 and 26 July.

${ }^{3}$ LMA, 9 and 10 August; MFGB, 16 August.

4 MFGB, ibid.

5 A. R. Griffin, The Miners of Nottinghamshire 1914-44 (London, 1962), p. 175.

- MFGB, ibid. 
Is Notts to be tolerated in the move they have made which makes for a break in the Federation". 1

By the beginning of September there were over 600 men back in Leicestershire, and morale was breaking up under the combined pressure of evidence of a massive return to work in Nottinghamshire and an intensive campaign by the Leicestershire owners to persuade their men to return to work, despite a threat by the LMA to withdraw safety men if blackleg labour was employed. ${ }^{2}$ Disillusionment with the failure of the MFGB to take advantage of the so-called "Bishops' Proposals" to solve what was already a four-month-old dispute must have acted in the same direction, particularly since the Leicestershire miners knew they could return to work at pre-stoppage terms whenever they chose to do so. ${ }^{3}$ Growdridge wrote to Cook on 13 September pointing out that "large and increasing numbers" of his members were returning to work, which was clear evidence that LMA "had lost grip of the men", and concluding that it would be best under the circumstances if "we met our owners locally and make arrangements providing a general settlement". 4 At the same time the following appeal was made in the press:

"That this Council learns with regret that large and increasing numbers of our members are returning to work, and notwithstanding the extenuating circumstances that may be the cause of the same express the hope that our members will remain loyal to their association and thereby help as a district association to maintain our collective bargaining power during future negotiations and while we arrange an organised resumption of work with the aid and consent of our Federation". 5

The concluding statement in the appeal was an ill-founded presumption by the LMA Executive because Cook shortly replied that the making of arrangements was contrary to Federation policy, ${ }^{6}$ and along with other important members of the MFGB Executive visited the coalfield no less than three times in a vain effort to bolster morale

1 Ibid.

2 Ibid., 2 September; LMA, 10 August. The Leicestershire owners were offering to take the men back at pre-lockout wages and hours according to $\mathrm{J}$. W. Smith, MFGB, 30 July.

${ }^{3}$ MFGB, 30 July. For details of the "Bishops' Proposals", see R. Page Arnot, The Miners: Years of Struggle (London, 1953), pp. 470-71.

4 LMA, 13 September.

5 Ibid.

${ }^{6}$ Ibid., 18 September. Cook reiterated this view during a meeting with the LMA Council on 19 September, when they resolved "to stand firm by Federation policy". 
of the rank and file, and persuade the Executive of the perils of making a district agreement with the owners. ${ }^{1}$ By the end of September 4,000 to 5,000 men were back at work, and it was reported to the LMA Executive on 9 October that " $90 \%$ of our members will be back at work by Monday 11 October". ${ }^{2}$ The Council's reaction was not altogether unpredictable: they passed a resolution, opposed only by Whitwick delegates, that all members, including members of the Council, should sign on and return to work by 13 October, and that a letter be written to Cook explaining that they had not officially called off the strike and made no agreement with the owners, but had simply resolved "that in view of the fact that $90 \%$ of our members are back at work we cannot ask our loyal members to stay out any longer". ${ }^{3}$ Some members expressed the view that the general return to work would mean their expulsion from the MFGB, and it was rumoured in certain London newspapers that the LMA was on the point of breaking away from the $\mathrm{MFGB}^{4}$ - a rumour that Growdridge denied in the local press while admitting that they had authorised a general return to work, though he deliberately avoided adding that there was indeed some pressure within the union for a breakaway. ${ }^{5}$ The Colliery Guardian claimed that the general resumption, at highly favourable terms for the men, was the outcome of a recent meeting between the LMA leaders and the owners, and predicted that "the steady return of large numbers of workmen to the pits has landed the Federation in a morass from which there is now no exit". ${ }^{6}$

The decision to resume work had been taken whilst Smith was away on the MFGB's fund-raising tour in Russia, and he steamed into the first meeting of the Council after his return exlaiming that "he would not serve, or receive payment from blacklegs", and after a "heated discussion" wrote the following: "I wish to state that I am desirous of serving only an organisation that is loyal to the Miners' Federation. If the Council cannot see its way clear to give the lead to the men then I shall be compelled to refuse to obey its dictates and work only on behalf of Federation members and in support of its policy." A proposal to accept Smith's resignation on the spot was

1 Coalville Times, 29 October.

${ }^{2}$ MFGB, 29 September; LMA, 9 October.

3 LMA, ibid.

${ }^{4}$ Coalville Times, 15 October; Colliery Guardian, 8 October.

5 Colliery Guardian, 15 October; Coalville Times, ibid. The Coalville Times reported that the men were returning to work at pre-stoppage rates and conditions, which were to remain in force until 30 June 1927, and that "news that the struggle had ended in Leicesterhire spread rapidly and was greeted with feelings of relief".

Colliery Guardian, 1 and 15 October. $\quad{ }^{7}$ LMA, 18 October. 
amended to one of "referring the matter of the agent's resignation to the Lodges". 1

On 21 October Cook, Herbert Smith and W. P. Richardson met the Council and explained that unless it revoked its decision to return to work the LMA would cease to be a member of the MFGB, and after a lengthy discussion, in which some members expressed opposition to a renewal of the dispute, it was decided to call all the members out again, though there was some support for a proposal that the members should be balloted on the issue. ${ }^{2}$ There is little doubt that such a ballot would have favoured a rejection of the MFGB's ultimatum because all attempts to bring the men out again failed miserably. There was a spate of mass meetings addressed by Cook, Herbert Smith and Richardson, at which Cook explained on one occasion: "We have not come here to abuse you but to ask you to redeem your souls", while Smith argued: "I am prepared to negotiate an honourable settlement tomorrow but I am not prepared to subscribe to an agreement which means peace at any price and slavery for the men I represent." 3 Smith also called branch meetings and flooded the coalfield with handbills. These efforts were opposed by many branch officials who advised members to boycott the meetings and use the handbills "for a suitable purpose", while the colliery-owners offered to pay every man who remained at work a bonus of $10 \%$ on his wages. ${ }^{4}$ Under these circumstances it is hardly surprising that Leicestershire's position was raised specifically at the MFGB Special Conference on 5 November, when the following exchange took place:

"The Chairman: Is Mr Smith, of Leicester, here? [...] I want to ask him a question, because he is a member of the Executive, and there is a report going up and down that the Leicester miners have signed an agreement. [...]

Mr. J. Smith (Leicester): There has been no agreement signed in relation to the men working in Leicester. [...]

The Chairman: Why I do that is because I don't want to be charged as Chairman with giving preferential treatment. We had to ask a certain district [Nottinghamshire] - one of their members retired. I was told that one of the members of the Executive, or his district, had gone one worse than what has been done there $[\ldots]$. It is quite true there is a division, a very big division in that Council [...]. Leicester has to be pulled together, and that is why I wanted to hear what he had to say. [...]

1 Ibid.

${ }^{2}$ Ibid., 21 October; Coalville Times, 22 October.

${ }^{3}$ Coalville Times, 29 October; LMA, 25 October; MFGB, 4-5 November.

${ }^{4}$ Coalville Times, ibid. and 5 November. 
Mr. G. Davies (South Wales): I want to be clear. When we dealt with Spencer and the other people from Notts, it was not a question of signing an agreement, it was a question of making arrangements. Will Mr. Smith be explicit and tell us whether there is an agreement made which is not signed?

The Chairman: What he is asking is this: Although there may not have been one signed, has there been one tacitly understood by your Council meeting with the owners? Have negotiations taken place? Mr. Smith: There is no understanding between our association and the owners. None whatever [...].

The Chairman: When we attended their Council meeting we were satisfied [...] that these men went back to work similarly to what men had gone back to work in other districts. The offers which were made tempted the men. I am not saying the check-weighmen were a bit weaker than others. There were one or two I could have put my finger on. However, we were satisfied there was no agreement or any negotiations that had taken place, except a visitation from house-to-house, with bribes in order to get them to go back to work."'

By the beginning of November there were 6,700 out of 7,000 men back at work and only about 300 members still loyal to Federation policy, ${ }^{2}$ and a Leicestershire delegate told the MFGB Conference: "I can only say that of the men in Leicester - and I don't want to boast about Jack Smith - but if they had taken a pattern from us there would have been a different tale to tell. The men have been undermined through the checkweighmen [usually branch officials]", ${ }^{3}$ while Smith told the same Conference:

"we have had some people preaching defeatism from the first day of the dispute, which has been responsible for so many men going back, and has been responsible for my district going back [...]. I want to say to those leaders of men [who have made defeatist speeches], it is either done deliberately or you do not

\footnotetext{
I MFGB, 10-13 November. At the previous MFGB Conference George Spencer, an official of the Nottinghamshire Miners' Association and a member of the MFGB Executive, had been dismissed from the meeting for admitting negotiating a return to work at a Nottinghamshire colliery on the request of his members working there. For details of the incident, see MFGB, 2 October, and A. R. Griffin, op. cit., pp. 183-89. Spencer went on to lead a breakaway trade union, the Nottinghamshire Miners' Industrial Union, and used this as a base for launching an abortive federation of non-political industrial trade unions in opposition to the MFGB. A. R. Griffin, pp. 221-36.

2 MFGB, 10-13 November.

Ibid.
} 
possess the intelligence you are supposed to have $[\ldots]$. I will stick it. I think there has been too much concern about loss of jobs in this business." 1

On 19 November the MFGB instructed the districts to negotiate district settlements. But this only added to the LMA's troubles because the owners informed the Council that they were "willing and anxious" to agree to a settlement, but "we very much regret that in view of the recent action and utterances of Smith we are of the opinion that he does not in any way represent the views of the majority of the men at work and consequently we are not prepared to meet him on any delegation." 2

Smith reported this position to the MFGB Conference, and added that there were still members of the LMA loyal to the Federation whom he did not feel able to order back to work but who were now being victimised, and asked the Conference for their advice on the situation. A delegate present exclaimed that he could not understand the purpose of the question since it was common knowledge that the LMA had instructed their members to return to work, whereupon the following exchange occurred:

"The Chairman: It is quite true that in the absence of my friend Smith - and I don't put that sarcastically - there was a vanishing from Leicester in his absence by people who ought not to have done, who advised the men to go to work. It is also quite true that he has never advised them as their representative to go back to work. Now, as far as Yorkshire is concerned, I am wanting all the men out now to stand to until I make the best bargain I can. $\mathrm{He}$ is standing to, and I think that Leicester has the same idea, but $[. .$.$] now that we have departed from the national policy;$ we have gone back to home rule, and Leicester has to decide the best policy for yourselves. If I can give any advice to John Smith, and advice is only for those who will take it, I should say: Face the facts. You have 300 honest men standing by you. For God's sake, don't sacrifice another man another moment if they can get work. I say that in fairness to those 300 men and Jack Smith too.

Mr. Smith: I thank you for your advice, your personal advice. I am a loyal member of this Federation and its rules and decisions, and I only asked the question because of the statement made here this morning. It is not long since another member of the

2 LMA, 29 November. 
Executive [Spencer] faced facts and ordered men to work and was dismembered.

Chairman: You are absolutely an impossibility. I have told you as a pal to a pal, that if $I$ were in Leicester and under your conditions [...] I should say: Nobody can save you, declare it off and get unemployment pay." 1

Smith took the advice: he officially called off the strike, advised those still out to obtain work if they could or sign on at the labour exchange. ${ }^{2}$ Meanwhile the Council decided that they could not accept the dictates of the owners on the election of their deputation - but after a great deal of pressure from several of its members this decision was reversed on 18 January $1927 . .^{3}$ A proposal that there should be a district ballot on the agent's position was defeated, and negotiations began without the presence of the fulltime official chiefly responsible for negotiation with the owners. ${ }^{4}$ On 1 February Smith resigned because he "could not bear the mental strain any longer" and felt, in any case, that this was the only way to clear up the position "until the men have expressed their opinion on the matter". 5 Smith's decision was a grave tactical error based, presumably, on the assumption that the Council would play fair and order a ballot, because they simply resolved to "clear up the matter" by accepting the resignation as final and stopping his salary forthwith. ${ }^{6}$ A few days later Smith wrote to the Council complaining that his position had not been put before the membership and received the reply that as far as they were concerned his connection with the LMA had ceased; ${ }^{7}$ a slap in the face which marked the beginning of a bitter feud between Smith and his former colleagues, which was to last for half a decade.

\section{II}

At the beginning of February 1927 John W. Smith stopped men leaving work at Whitwick and Snibstone collieries, and tried to persuade them to leave the LMA and join a breakaway organisation led by himself. Shortly afterwards the "New Miners Union", as it was called, opened an office close by Whitwick colliery gates. ${ }^{8}$ By the third week in February Smith was conducting a vigorous recruiting campaign, and

1 MFGB, 26 November.

2 Coalville Times, 3 December.

3 LMA, 29 November 1926 and 18 January 1927.

4 Ibid., 18 and 31 January 1927.

5 Ibid., 3 February.

"Ibid.

7 Ibid., 14 February.

8 Ibid.; Coalville Times, 25 February. 
at a public meeting at Whitwick argued that the LMA had "gone right down to the bottom" and was in effect "a bosses' union", whereas the New Miners' Union would be a "foolproof union in this district", which would be "the true representative of men's interests" and would seek recognition from the MFGB as the legitimate representative of the Leicestershire miners. He also claimed that he had been forced to resign at the instigation of the owners, who objected to him because "I am a fierce negotiator who always stood for the rights of the men on all occasions", and because he had many successful negotiations to his credit which the owners resented. ${ }^{1}$

The LMA Council retaliated by forbidding Smith ever to enter the LMA's premises again, and stamped out any sympathy or support for him within its own ranks on the grounds that such conduct was detrimental and disloyal. In this purge the office-cleaner was dismissed for giving Smith a lamp and two partly filled gallon petrol cans, which he had claimed were his own personal property, and the secretary of Ellistown Lodge was unconstitutionally dismissed for making a statement in Smith's support. ${ }^{2}$ The Council also attempted to combat Smith's propaganda by a slur campaign, he was accused of neglecting the district during the strike, making revolutionary speeches in Russia and living there in the lap of luxury while still receiving expenses from the LMA. They urged the members to remember the old adage "United we stand, divided we fall", and added as sufficient rebuttal of Smith's arguments: "Your officials can afford to treat with contempt the slanderous accusations being made by that fellow Smith.",3

The MFGB, however, could not afford the same luxury because they were faced with the unprecedented situation of a breakaway from an affiliated union, led by a man who had been a prominent member of their own Executive, asking for recognition on the ground that it represented the Leicestershire miners who were loyal to Federation policy. The LMA had about 2,500 members and the breakaway about one-tenth of that number, if its weekly contributions is any indication of its strength, ${ }^{4}$ and the MFGB Executive appealed to the LMA to re-establish unity by re-instating Smith. The LMA obstinately refused even to discuss the issue, and eventually even brusquely rejected a personal appeal by Cook himself. ${ }^{5}$ Fortunately for the MFGB, Smith

1 Coalville Times, 18 and 25 February.

2 LMA, 21 February.

${ }^{3}$ Coalville Times, 4 and 11 February, 4 March; Colliery Guardian, 4 and 25 February, 4 and 11 March.

4 LMA, 9 March; Coalville Times, 25 February.

- LMA, 26 February, 9 March, 11 April, 2 May, 10 June and 21 July; MFGB, 3 March, 13 April and 12 May. 
had agreed to wind up the breakaway after a meeting with the Executive early in March, on the understanding that they would obtain his re-instatement, ${ }^{1}$ and when they failed to do so Smith left Coalville for the county town, where he started up an icecream-selling business which failed after a couple of months. He then left for London, where he was unable to obtain permanent employment, and so he returned to Coalville after spending a month sleeping in dosshouses or on the Embankment. ${ }^{2}$

Despite the demise of the New Miners' Union, Smith's position continued to be an embarrassment to the MFGB until June, when the following exchange at a special conference occurred:

"A delegate: I would like to ask the Leicester delegate [Growdridge] if he knows anything about the working of the Non-political Union, and if it is not a fact that the position of Jack Smith has something to do with non unionism?

The Chairman: We have got to deal with Leicester as it is, and not say whether it is Jack Smith or anybody else. We have got to take our Leicester friends as they are and try to bring them into the fold. They may not be moving like us. Don't ask any more questions. I have been through an election there and I had to smile on two men."'3

Thereafter the name of Jack Smith was heard no more at the MFGB Conferences though this should not be taken to mean that Smith himself was silenced, for in November 1927 he held a series of meetings at Coalville to ascertain "whether the miners still had confidence in him", and reiterated his complaint that he had only tended his resignation on the understanding that the members would be balloted on his position. ${ }^{4}$ The LMA decided to submerge Smith's new campaign for re-instatement with a "back to the union" one of its own, and when it was suggested at a public meeting that the best method of increasing membership was to re-appoint Smith as agent, Growdridge replied that they could no longer afford to employ one agent. ${ }^{5}$ Smith's

1 Colliery Guardian, 11 March.

2 Coalville Times, 11 November.

${ }^{8}$ MFGB, 2 June. Several members of the LMA Council had been advocating that their organisation should sever links with the MFGB and form itself into a non-political trade union on the lines of Spencer's Nottinghamshire Miners' Industrial Union. A. R. and C. P. Griffin, "The Non-Political Trade Union Movement", in: Essays in Labour History 1918-1939, ed. by A. Briggs and J. Saville (London, 1977), pp. 137-38. As we have seen, J. W. Smith's attitude towards the LMA was that it was already a non-political trade union in all but name.

4 Coalville Times, 11 November.

5 Ibid, 18 November and 9 December. 
new appeal failed to achieve its objective, but he was not content to sink completely into the oblivion conjured up for him by the LMA Council, for he was still attacking them in July 1931 when they finally instructed Growdridge "to take any steps necessary, including proceedings", to silence him forever. ${ }^{1}$ This time they probably succeeded, for this once fiery member of the MFGB Executive reputedly ended his career sweeping the streets of the county town in the 1930's. ${ }^{2}$

\section{III}

At the end of 1927 the LMA had a membership of 3,000 and funds of $£ 8,591$, and now had only one permanent official, the self-styled general secretary Thomas Growdridge. ${ }^{3}$ Morale among the rank and file was at a low ebb, largely because of the disillusionment felt at the failure of the strike, and partly because of the deplorable manner in which Smith had been used as a scapegoat for the LMA's difficulties. ${ }^{4}$ The LMA remained affiliated to the MFGB, although relations between the two organisations continued to be strained because of the residue of bitterness lingering from 1926 and the LMA's subsequent misdemeanours, such as its refusal to pay into the political levy or buy the MFGB's newspaper, The Miner. ${ }^{5}$ The presence of the LMA officials, particularly Growdridge, at the MFGB Conferences was a constant reminder of the impotence and confusion to which it had been reduced in the last days of the strike and the first few months of peace. The MFGB Conference had ignominiously expelled George Spencer, the Nottinghamshire leader and member of the MFGB Executive, on 8 October for making an arrangement for an organised return to work at two collieries, but then failed to take similar action when an entire affiliated association returned en bloc to work a week later through fear of weakening the strength of the Federation further. ${ }^{6}$

1 LMA, 31 July 1931.

${ }^{2}$ Personal interview with Mr Frank Smith, the present agent of the LMA and a member of his namesake's abortive New Miners' Union.

3 Annual Report of the Chief Registrar of Friendly Societies, 1927; LMA, 21 July 1927.

4 MFGB, 2 June; Coalville Times, 9 December. LMA, 6 February 1928, records that only "very small numbers of members" were attending lodge meetings.

5 LMA, 14 October 1927; A. R. and C. P. Griffin, loc. cit., p. 138.

6 It is fairly clear, even from Herbert Smith's own evidence to the MFGB Conference on 5 November 1926, in which he justified his inaction on the matter, that some "back room" negotiations had been taking place between representatives of the owners and members of the LMA Council. It was common knowledge according to the Coalville Times (15 October) that the miners were returning on the basis of a definite offer made by the owners. 
This failure was also a tacit admission that Spencer's dismissal, and the Spencer-led Nottinghamshire breakaway which inevitably followed resulted from an error of judgement on the part of the MFGB, which was emphasised by the chaotic conditions in which the lockout ultimately collapsed. ${ }^{1}$ Moreover, weakness at the end of 1926 and during 1927 had meant that MFGB officials had been ordered to "smile on" members of the LMA Council, who proposed that the LMA should follow Spencer's road, and the LMA remained, as Herbert Smith noted, a fellow-traveller of Nottinghamshire Miners' Industrial Union within the ranks of an organisation pledged to stamp it out. At the same time the MFGB Executive had been unable to assist the endeavours of one of their most loyal and active members to gain reinstatement into that same union after being unjustly dismissed.

The Leicestershire experience examined here undoubtedly lends support to the conclusions of the latest general study of the miners' lockout of 1926 that "The miners had lost everything. The MFGB was now penniless and powerless. [...] Unity had collapsed and the old regional rivalries had begun to assert themselves again." 2 But, more importantly, it also highlights an hitherto neglected, yet significant, dimension of the dispute and its aftermath, and helps to explain just how great was the catastrophe which hit both the miners' district unions and the MFGB in 1926.

1 Conditions which. as we have seen, completely bewildered J. W. Smith. For a general description of the last days of the dispute see Arnot, op. cit., pp. 499-506. ${ }_{2}^{2}$ P. Renshaw, The General Strike (London, 1975), p. 230. 